\section{Public Health} Genomics
Public Health Genomics 2013;16:192-197

DOI: $10.1159 / 000352014$
Received: February 6, 2013

Accepted after revision: May 14, 2013

Published online: July 11, 2013

\title{
Viral Hepatitis C Gets Personal - The Value of Human Genomics to Public Health
}

\author{
L. Zhang ${ }^{\text {a }}$ M. Gwinn ${ }^{\text {b }}$ D.J. Hu ${ }^{\text {a }}$ \\ ${ }^{a}$ Division of Viral Hepatitis, National Center for HIV/AIDS, Viral Hepatitis, STD, and TB Prevention, Centers for Disease \\ Control and Prevention, and ${ }^{\mathrm{b}}$ McKing Consulting Corporation, Atlanta, Ga., USA
}

\section{Key Words}

Hepatitis C $\cdot$ Host genetic predisposition to disease $\cdot$ IL28B

polymorphism $\cdot$ Interferon response

\begin{abstract}
About 180 million people worldwide are chronically infected with hepatitis $\mathrm{C}$ virus (HCV), with 3-4 million newly infected each year. Only $15-25 \%$ of acute HCV infections clear spontaneously, and the remainder persists as chronic HCV infection. More than 350,000 people die every year from hepatitis $\mathrm{C}$-related liver failure and cancer. There is currently no vaccine and the standard-of-care therapies - peg-interferon alpha (pegIFN) plus ribavirin (RBV) - are expensive and have serious side effects. Also, they may be effective in only 40 $50 \%$ of patients infected with HCV genotype 1 , the most common HCV genotype in the US. Interleukin 28B (IL28B) genotype was recently and convincingly associated with response to pegIFN and RBV therapy. It has emerged as a robust pretreatment predictor of sustained virological response (SVR, i.e. virologic clearance) to pegIFN and RBV as well as to new triple therapy regimens that include a directacting antiviral agent with pegIFN and RBV and increase SVR rates as much as $75 \%$ in patients infected with $\mathrm{HCV}$ genotype 1. Testing for IL28B genotype may contribute to clinical decision-making and could inform clinical guidelines and public health policies.

(c) 2013 S. Karger AG, Basel
\end{abstract}

(c) 2013 S. Karger AG, Basel

$1662-4246 / 13 / 0164-0192 \$ 38.00 / 0$

\section{Introduction and Epidemiology}

Hepatitis $\mathrm{C}$ is an infectious disease primarily affecting the liver caused by the hepatitis $\mathrm{C}$ virus (HCV). It can range in severity from a mild illness lasting a few weeks to a serious, lifelong illness. HCV, a bloodborne pathogen endemic in most parts of the world, infects an estimated 180 million people worldwide and causes 3-4 million new infections annually [1]. Only 15-25\% of acutely infected individuals spontaneously clear $\mathrm{HCV}$, while the remainder progress to chronic HCV infection and are, therefore, at risk for cirrhosis and hepatocellular carcinoma. Despite the serious illness it can cause, hepatitis $\mathrm{C}$ infection is often asymptomatic for many years or decades. Hepatitis $C$ has been called a 'silent epidemic' because most infected people are unaware that they have a serious and progressive chronic disease.

In the US, hepatitis C mortality has increased substantially since the 1990s. Despite small declines and leveling of incidence overall in recent years, reports of HCV infection are increasing in some areas of the US $[2,3]$. Current trends in HCV infection include an apparent increase in young, often suburban heroin injection drug users, infections in nonhospital healthcare (clinic) settings, and sexual transmission among persons infected with human immunodeficiency virus (HIV) [4]. Approximately 25\% of persons with HIV infection are coinfected with HCV;

\section{KARGER}

E-Mail karger@karger.com

www.karger.com/phg
Lyna Zhang, DPhil, MD

Division of Viral Hepatitis, National Center for HIV/AIDS, Viral Hepatitis, STD, and TB Prevention, Centers for Disease Control and Prevention 1600 Clifton Road NE, MS A33

Atlanta, GA 30333 (USA), E-Mail chn6@cdc.gov 
both infections are associated with injection drug use [5]. In the absence of increased screening and treatment, models project an additional 165,900 deaths from chronic liver disease, 27,200 deaths from hepatocellular carcinoma and USD 10.7 billion in direct medical expenditures for HCV from 2010 through 2019 [6, 7].

Hepatitis $\mathrm{C}$ infection has a great propensity to cause chronic hepatitis, which occurs in $70-80 \%$ of those acutely infected [8]. This often persists and slowly worsens over $10-20$ years. After acute infection, only $15-25 \%$ of persons with normal immune status resolve their infection without sequelae. End-stage liver disease can also occur. In $10-20 \%$ of chronically infected persons, cirrhosis develops slowly over 20-30 years, and hepatocellular carcinoma develops in $1-5 \%$. Progression to liver fibrosis, development of cirrhosis and subsequent mortality are associated with age at infection, duration of HCV infection, HCV genotype, HIV coinfection, alcohol use, and male sex [8].

\section{Hepatitis C Virus}

$\mathrm{HCV}$ is an enveloped RNA virus within the Flaviviridae family. Its genome consists of a positive-stranded RNA molecule (about $9.6 \mathrm{~kb}$ ) that encodes a large polyprotein precursor (about 3,000 amino acids). This precursor protein is cleaved by host and viral proteinases to generate at least 10 proteins. These HCV proteins function in viral replication and affect a variety of host cellular functions [9].

The genome of HCV is highly mutable. Because HCV is an RNA virus and lacks efficient proofreading ability as it replicates, virions infecting humans undergo evolution with time, giving rise to the notion that $\mathrm{HCV}$ persists as a collection of virus quasispecies. By constant mutation in a hypervariable region of the genome coding for the envelope proteins, HCV escapes immune surveillance and elimination by the host. As a consequence, most $\mathrm{HCV}$ infected people develop chronic infection [9].

$\mathrm{HCV}$ is highly heterogeneous. Six major genotypes (numbered from 1-6) with several distinct subtypes have been identified throughout the world [10]. Genotypes 1a and $1 \mathrm{~b}$ are found worldwide and cause approximately $60 \%$ of all cases of infection. This diversity has distinct consequences: different genotypes vary in their responsiveness to treatment (see below) and their propensity to cause insulin resistance, steatosis, and progression to cirrhosis, fibrosis and hepatocellular carcinoma. For example, patients infected with $\mathrm{HCV}$ genotypes 1 or 4 tend to be more resistant to IFN-based therapies than genotypes 2 or 3 [11]. Genetic variation within the core, E2, NS2, P7, NS5A, and NS5B proteins appears to be related to IFN resistance [12] by interfering with IFN pathways and antiproliferative activity and contributing to carcinogenesis [13].

\section{Host Interferon Response to HCV Infection}

HCV does not kill the cells it infects, but triggers an immune-mediated inflammatory response (hepatitis) that either rapidly clears the infection or slowly destroys the liver, resulting in the development of cirrhosis and liver cancer. The outcome is largely determined by the efficiency of the antiviral immune response. [14]. The strong interferon response to $\mathrm{HCV}$ infection produces IFN $-\beta$ secretion from the infected cell. IFN- $\beta$ binding to the IFN $-\alpha / \beta$ receptor signals the Janus kinase/signal transducer and activator of transcription (JAK/STAT) pathway, which leads to upregulation of several hundred interferon-stimulated genes (ISGs). ISG products impart viral regulatory functions that limit HCV replication by disrupting viral RNA translation and inhibiting antigenomic strand RNA synthesis. In addition to its direct antiviral actions, IFN primes the maturation of immune effector cells and potentiates the production of other proinflammatory cytokines by resident hepatic cells; this process indirectly modulates cell-mediated defenses and adaptive immunity to HCV [14]. Current IFN-based therapy exploits the mechanism of induction of ISG expression through the IFN- $\alpha / \beta$ receptor and JAK/STAT pathway to provide antiviral action against HCV [12].

\section{Treatment}

Chronic HCV infection imposes a major public health burden in part because therapy may not be effective and usually has major side effects. HCV elimination is operationally defined as causing a sustained virological response (SVR) in which HCV RNA levels cannot be detected in blood 6 months after cessation of therapy [15]. A combination therapy with peg-interferon alpha (pegIFN) and ribavirin (RBV) is effective in eliminating $\mathrm{HCV}$ in only about half of patients treated [16]. Success rates are even lower in certain subpopulations, such as African Americans, who have an almost 50\% reduction in SVR rates with pegIFN and RBV compared with Caucasians [17]. Another class of drugs recently approved for use by 
the FDA - direct-acting antiviral agents (DAA), such as telaprevir or boceprevir - cause antiviral resistance and virological breakthrough when used as solo therapy. However, triple-regimen therapy with a DAA plus pegIFN and RBV greatly enhances SVR rates, up to $75 \%$ in patients with genotype 1 chronic HCV infection, the most prevalent genotype in the US; DAAs are not yet widely available or are too costly in most of the world $[15,18$ 20].

Because IFN is the backbone of all therapeutic regimens, identifying factors that affect the response to IFN therapy is important for clinical decision-making. Several pre- and on-treatment host and viral variables have been associated with treatment outcome, and some of these have become part of decision-making for treatment [21]. Young age, female gender, lower weight, normal serum glucose, absence of hepatic steatosis, no or minimal fibrosis on liver biopsy, adherence to therapy, lower baseline viral load, and genotypes 2 and 4 are positive predictors of SVR [17]. One of the most important predictors of SVR when using a combination therapy of pegIFN and $\mathrm{RBV}$ is the specific host IL28B genotype [22].

\section{Host IL28B Genotype, Ethnicity and Response to Interferon Treatment}

In late 2009 and early 2010, the association between the IL28B genotype and treatment outcome in HCV genotype 1 infection was made by 4 independent groups in genome-wide association studies [23-26]. All found that single nucleotide polymorphisms (SNPs) rs12979860 and rs8099917 - which tag a haplotype block on chromosome 19 that spans $I L 28 B$ - strongly predict the outcome of pegIFN and RBV treatment in patients infected with $\mathrm{HCV}$ genotype 1 . This finding was consistent among different racial and ethnic populations (African American, Asian, Caucasian, and Hispanic). The SNP most associated with SVR in Caucasians is rs12979860, whereas in Asians it seems to be rs8099917. Individuals carrying the favorable response genotype, containing either rs12979860-CC or rs8099917-TT, are at least twice as likely to attain SVR [27-30]. In most populations, except African Americans, these 2 SNPs are in strong linkage disequilibrium and similarly informative.

The frequency of the favorable response genotype differs across racial/ethnic populations, being most frequent in Asians (73\%), least frequent in African Americans (13\%) and with an intermediate frequency in Caucasians (41\%) and Hispanics (25\%) [23-26, 28, 30]. Although the favorable response genotype has a similar effect on treatment response in all racial/ethnic groups (Caucasians, odds ratio $(\mathrm{OR})=3.88,(95 \% \mathrm{CI})=(2.75-5.49)$; African American, $\mathrm{OR}=4.63(2.52-8.50) ;$ Asians, $\mathrm{OR}=5.66$ (3.99-8.02); pooled $\mathrm{OR}=4.68(3.75-5.83)$ ), its differential distribution contributes very strongly to observed racial disparities in overall treatment response [28]. Indeed, African American patients with a favorable genotype respond better than Caucasian patients with an unfavorable genotype [23]. However, the IL28B genotype does not account for all of the racial differences in response to treatment; both $I L 28 B$ genotype and ethnic background independently predict SVR [31].

Several studies have found that IL28B variants are also associated with likelihood of spontaneous clearance of HCV infection. [25, 32-34]. Patients who carry the favorable response genotype are twice as likely to clear acute $\mathrm{HCV}$ infection without treatment ( $\mathrm{rs} 12979860-\mathrm{CC}, \mathrm{OR}=$ 3.75 (2.42-5.81); rs8099917-TT, OR = $2.67(1.82-3.91)$ ) [34]. The relationship of IL28B genotype with pegIFN and RBV treatment outcome is similar in patients infected with only HCV and those coinfected with HCV and HIV [30, 35]. However, IL28B genotype has no effect on outcomes of HIV or HBV infection or elite control of HIV infection [36-38].

The consistently replicated association of genetic variants of $I L 28 B$ with treatment outcome suggests that its product, interferon lambda 3 (IFN- $\lambda 3$ ), has an important role in determining viral clearance [39]. The 3 IFN- $\lambda s$ coded by IL28A, IL28B and IL29 were originally discovered in 2003 through computational prediction of previously unknown proteins from genomic sequence data. The signaling and biological activities of these 3 IFN- $\lambda$ s overlap with IFN- $\alpha$, signaling via the same JAK/STAT pathway leading to induction of IGS expression and antiviral proteins. IFN- $\lambda 1 / 2$ have shown antiviral activity against $\mathrm{HCV}$ in vitro, although they are less potent than IFN-a. In a phase 1 study of patients with genotype 1 chronic HCV infection, pegIFN $-\lambda 1$ had potent antiviral activity and resulted in a better side-effect profile than IFN- $\alpha$ [40]. These outcomes might be due to the fact that the common receptor (IFN- $\lambda \mathrm{R}$ ) shared by IFN- $\lambda$ s has a more liver-specific distribution than IFN- $\alpha$ R. It seems highly likely that the IFN- $\lambda$ axis will lead to viable therapeutic options in the near future.

IL28B variants are the strongest baseline predictor of SVR to pegIFN plus RBV in treatment-naïve patients with genotype $1 \mathrm{HCV}$ in multivariable models with other independent predictors such as race, baseline viral load, hepatic fibrosis stage, and fasting glucose level, 
across different racial and ethnic populations (African American, Asian, Caucasian, and Hispanic) [23, 41, 42]. Patients infected with HCV genotype 1 who have a favorable $I L 28 B$ genotype have a $65 \%$ chance of cure with pegIFN and RBV. The favorable IL28B response genotype is associated with more rapid viral kinetics and improved the treatment outcome independent of ISG expression [41].

\section{IL28B Genotype in the Era of DAAs}

The treatment regimen for chronic HCV is currently undergoing a major change with the introduction of DAAs. DAAs directly inhibit specific steps in the HCV viral life cycle, for example, currently approved boceprevir and telaprevir target NS3 protease. Boceprevir or telaprevir in combination with pegIFN and RBV are now considered as optimal therapy for chronic HCV genotype 1 infection; both therapies must be given with pegIFN and RBV to limit selection of resistant variants and improve antiviral response $[15,22,43]$. Triple therapy with boceprevir or telaprevir improves on-treatment kinetics and increases achieved SVR rates.

Initial data suggest that $I L 28 B$ genotype also predicts the response to DAA therapy, although its predictive effect might not be as strong as for dual therapy with pegIFN and RBV [44]. Patients with favorable IL28B genotype achieve $70 \%$ SVR with standard therapy and up to 90\% achieve SVR with triple therapy. The major benefit of DAA appears to be to allow short treatment duration [45]. Patients with an unfavorable IL28B genotype have the most to gain from the addition of DAA, which doubles the SVR rate in this group (30\% with pegIFN and RBV only, and $70 \%$ with triple therapy); for these patients, the cost-effectiveness and risk-benefit will be more favorable [45].

\section{Public Health Implications}

Currently, an estimated 3.2 million Americans are living with hepatitis $\mathrm{C}$ in the US, most of whom (2.1 million) were born from 1945 through 1965 (the 'baby boomers'). However, up to 1.5 million baby boomers have not sought medical treatment because they do not know they are infected. To limit HCV-associated morbidity and mortality, the Centers for Disease Control and Prevention recently recommended a one-time hepatitis $\mathrm{C}$ test for adults born during 1945-1964 to identify infected persons and link them to care and treatment $[46,47]$. This recommendation follows an action plan for prevention, care, and treatment of viral hepatitis issued by the US Department of Health and Human Services in 2011 [48]. Implementation of this approach could identify 800,000 additional $\mathrm{HCV}$ infections and prevent more than 120,000 deaths by providing these patients with appropriate treatment [46, 47]. IL28B genotype testing could be part of a cost-effective strategy that also improves individual outcomes [49]; a commercial test for IL $28 B$ is now available for about USD 300, needed to be performed only once in a patient's life [31].

DAA causes more severe adverse effects than pegIFN and RBV alone [50]; because it is costly (USD 1,100 per week for boceprevir, USD 4,100 per week for telaprevir and USD 954 per week for pegIFN and RBV), access to DAA could be restricted. Universal triple therapy with boceprevir (USD 1,100 per week) in all HCV genotype 1 infected patients in the US would cost an additional USD 102,600 per quality adjusted life year (QALY) gained in the setting of mild fibrosis, compared with the standard dual therapy with pegIFN and RBV. Using IL28B guided triple therapy could improve cost-effectiveness; for example, treating only those patients with unfavorable IL28B genotypes with a protease inhibitor would cost USD 70,100 per QALY in those with mild fibrosis or USD 36,300 per QALY with advanced fibrosis in addition to therapy with pegIFN and RBV therapy alone [49]. IL28B genotype identifies patients who are likely to attain SVR with a shorter, lower-cost regimen (pegIFN and RBV alone); therefore, genetic testing could be helpful in maximizing the cost-effectiveness of triple therapy. For example, offering patients with favorable IL28B genotypes first-line treatment with pegIFN and RBV, followed by DAA for those who relapse, could be more cost-effective than treating all patients initially with regimens including DAA $[45,49]$.

As there is substantial overlap between persons infected with HCV and HIV, coinfected individuals represent an important subgroup with chronic HCV infection being one of the leading causes of morbidity and mortality among persons with HIV infection [51]. Despite the introduction of promising therapies and the ability to assess therapy response through $I L 28 B$ testing, treatment uptake for HCV is unacceptably low, especially among substance abusers. Increasing the awareness of these diagnostic and treatment advances among health care providers may help to improve treatment uptake among all individuals with chronic HCV infection [51]. 


\section{Conclusion}

$I L 28 B$ variation is strongly associated with response to pegIFN plus RBV therapy in patients chronically infected with HCV genotype 1 . This discovery has been consistently replicated in many populations. IL28B genotype is a strong predictor of treatment outcome at the individual level. Even with the introduction of a new class of highly effective DAAs, the IL $28 B$ genotype continues to serve as a useful predictor of treatment outcome and could help to establish treatment expectations and guide decisions for retreatment of prior nonresponders as long as IFN continues to be the backbone for antiviral therapy. Test- ing for $I L 28 B$ variants predictive of therapeutic success should contribute substantially to clinical decision-making and formulation of public health policies. The goal of personalized healthcare may be one step closer for patients with $\mathrm{HCV}$ infection.

\section{Acknowledgement}

This study was supported by the Centers for Disease Control and Prevention, Atlanta, Ga. The findings and conclusions in this report are those of the authors and do not necessarily represent the views of the Centers for Disease Control and Prevention.

\section{References}

1 Lavanchy D: The global burden of hepatitis C. Liver Int 2009;29(suppl 1):74-81.

2 Wise M, Bialek S, Finelli L, Bell BP, Sorvillo F: Changing trends in hepatitis C-related mortality in the United States, 1995-2004. Hepatology 2008;47:1128-1135.

3 Ly KN, Xing J, Klevens RM, Jiles RB, Ward JW, Holmberg SD: The increasing burden of mortality from viral hepatitis in the United States between 1999 and 2007. Ann Intern Med 2012;156:271-278.

-4 Klevens RM, Hu DJ, Jiles R, Holmberg SD: Evolving epidemiology of hepatitis $\mathrm{C}$ virus in the United States. Clin Infect Dis 2012;55 (suppl 1):S3-9.

5 Spradling PR, Richardson JT, Buchacz K, Moorman AC, Finelli L, Bell BP, Brooks JT; Investigators HIVOS: Trends in hepatitis C virus infection among patients in the HIV outpatient study, 1996-2007. J Acquir Immune Defic Syndr 2010;53:388-396.

6 Wong JB, McQuillan GM, McHutchison JG, Poynard T: Estimating future hepatitis C morbidity, mortality, and costs in the United States. Am J Public Health 2000;90:15621569.

7 Davis KL, Mitra D, Medjedovic J, Beam C, Rustgi V: Direct economic burden of chronic hepatitis $\mathrm{C}$ virus in a United States managed care population. J Clin Gastroenterol 2011; 45:e17-24.

8 Seeff LB: Natural history of chronic hepatitis C. Hepatology 2002;36(5 suppl 1):S35-S46.

$\checkmark 9$ Kato N: Genome of human hepatitis $\mathrm{C}$ virus (HCV): gene organization, sequence diversity, and variation. Microb Comp Genomics 2000;5:129-151.

10 Simmonds P, Bukh J, Combet C, Deleage G, Enomoto N, Feinstone S, Halfon P, Inchauspe G, Kuiken C, Maertens G, Mizokami M, Murphy DG, Okamoto H, Pawlotsky JM, Penin F, Sablon E, Shin IT, Stuyver LJ, Thiel HJ,
Viazov S, Weiner AJ, Widell A: Consensus proposals for a unified system of nomenclature of hepatitis C virus genotypes. Hepatology 2005;42:962-973.

11 Chayama K, Hayes CN: Hepatitis C virus: how genetic variability affects pathobiology of disease. J Gastroenterol Hepatol 2011;26 (suppl 1):83-95.

12 Feld JJ, Hoofnagle JH: Mechanism of action of interferon and ribavirin in treatment of hepatitis C. Nature 2005;436:967-972.

13 Chen HM, Tanaka N, Mitani Y, Oda E, Nozawa H, Chen JZ, Yanai H, Negishi H, Choi MK, Iwasaki T, Yamamoto $\mathrm{H}$, Taniguchi T, Takaoka A: Critical role for constitutive type I interferon signaling in the prevention of cellular transformation. Cancer Sci 2009;100: 449-456.

14 Gale M Jr, Foy EM: Evasion of intracellular host defence by hepatitis $\mathrm{C}$ virus. Nature 2005;436:939-945.

15 Ghany MG, Nelson DR, Strader DB, Thomas DL, Seeff LB; American Association for Study of Liver Diseases: an update on treatment of genotype 1 chronic hepatitis $C$ virus infection: 2011 practice guideline by the American Association for the Study of Liver Diseases. Hepatology 2011;54:1433-1444.

16 McHutchison JG, Lawitz EJ, Shiffman ML, Muir AJ, Galler GW, McCone J, Nyberg LM, Lee WM, Ghalib RH, Schiff ER, Galati JS, Bacon BR, Davis MN, Mukhopadhyay P, Koury K, Noviello S, Pedicone LD, Brass CA, Albrecht JK, Sulkowski MS; IDEAL Study Team: Peginterferon alfa- $2 \mathrm{~b}$ or alfa-2a with ribavirin for treatment of hepatitis $\mathrm{C}$ infection. $\mathrm{N}$ Engl J Med 2009;361:580-593.

17 Howell CD, Dowling TC, Paul M, Wahed AS, Terrault NA, Taylor M, Jeffers L, Hoofnagle JH; Virahep-C Study Group: Peginterferon pharmacokinetics in African American and Caucasian American patients with hepatitis C virus genotype 1 infection. Clin Gastroenterol Hepatol 2008;6:575-583.

18 Hézode C, Forestier N, Dusheiko G, Ferenci $\mathrm{P}$, Pol S, Goeser T, Bronowicki JP, Bourlière M, Gharakhanian S, Bengtsson L, McNair L, George S, Kieffer T, Kwong A, Kauffman RS, Alam J, Pawlotsky JM, Zeuzem S; PROVE2 Study Team: Telaprevir and peginterferon with or without ribavirin for chronic HCV infection. N Engl J Med 2009;360:18391850.

19 Poordad F, McCone J Jr, Bacon BR, Bruno S, Manns MP, Sulkowski MS, Jacobson IM, Reddy KR, Goodman ZD, Boparai N, DiNubile MJ, Sniukiene V, Brass CA, Albrecht JK, Bronowicki JP; SPRINT-2 Investigators: Boceprevir for untreated chronic HCV genotype 1 infection. N Engl J Med 2011;364:11951206.

20 Jacobson IM, McHutchison JG, Dusheiko G, Di Bisceglie AM, Reddy KR, Bzowej NH, Marcellin P, Muir AJ, Ferenci P, Flisiak R, George J, Rizzetto M, Shouval D, Sola R, Terg RA, Yoshida EM, Adda N, Bengtsson L, Sankoh AJ, Kieffer TL, George S, Kauffman RS, Zeuzem S; ADVANCE Study Team: Telaprevir for previously untreated chronic hepatitis C virus infection. N Engl J Med 2011;364: 2405-2416.

21 Kau A, Vermehren J, Sarrazin C: Treatment predictors of a sustained virologic response in hepatitis B and C. J Hepatol 2008;49:634-651.

22 Thompson AJ: Genetic factors and hepatitis C virus infection. Gastroenterology 2012;142: 1335-1339.

23 Ge D, Fellay J, Thompson AJ, Simon JS, Shianna KV, Urban TJ, Heinzen EL, Qiu P, Bertelsen AH, Muir AJ, Sulkowski M, McHutchison JG, Goldstein DB: Genetic variation in $I L 28 B$ predicts hepatitis C treatment-induced viral clearance. Nature 2009; 461:399-401. 
24 Tanaka Y, Nishida N, Sugiyama M, Kurosaki M, Matsuura K, Sakamoto N, Nakagawa M, Korenaga M, Hino K, Hige S, Ito Y, Mita E, Tanaka E, Mochida S, Murawaki Y, Honda M, Sakai A, Hiasa Y, Nishiguchi S, Koike A, Sakaida I, Imamura M, Ito K, Yano K, Masaki N, Sugauchi F, Izumi N, Tokunaga K, Mizokami M: Genome-wide association of IL28B with response to pegylated interferon-alpha and ribavirin therapy for chronic hepatitis $\mathrm{C}$. Nat Genet 2009;41:1105-1109.

25 Rauch A, Kutalik Z, Descombes P, Cai T, Di Iulio J, Mueller T, Bochud M, Battegay M, Bernasconi E, Borovicka J, Colombo S, Cerny A, Dufour JF, Furrer H, Gunthard HF, Heim M, Hirschel B, Malinverni R, Moradpour D, Mullhaupt B, Witteck A, Beckmann JS, Berg T, Bergmann S, Negro F, Telenti A, Bochud PY; Swiss Hepatitis C Cohort Study; Swiss HIV Cohort Study: Genetic variation in IL28B is associated with chronic hepatitis C and treatment failure: a genome-wide association study. Gastroenterology 2010;138: 1338-1345, 1345 e1-7.

-26 Suppiah V, Moldovan M, Ahlenstiel G, Berg T, Weltman M, Abate ML, Bassendine M, Spengler U, Dore GJ, Powell E, Riordan S, Sheridan D, Smedile A, Fragomeli V, Muller T, Bahlo M, Stewart GJ, Booth DR, George J: IL28B is associated with response to chronic hepatitis $c$ interferon-alpha and ribavirin therapy. Nat Genet 2009;41:1100-1104.

-27 Li S, Hu P, Zhang QQ, Liu YH, Hu HD, Zhang DZ, Ren H: Single nucleotide polymorphisms of the IL28B and sustained virologic response of patients with chronic hepatitis C to PEGinterferon/ribavirin therapy: a meta-analysis: meta-analysis of IL28B. Hepat Mon 2011;11: 163-172.

-28 Rangnekar AS, Fontana RJ: Meta-analysis: IL28B genotype and sustained viral clearance in HCV genotype 1 patients. Aliment Pharmacol Ther 2012;36:104-114.

29 Chen Y, Xu HX, Wang LJ, Liu XX, Mahato RI, Zhao YR: Meta-analysis: IL28B polymorphisms predict sustained viral response in $\mathrm{HCV}$ patients treated with pegylated interferon-alpha and ribavirin. Aliment Pharmacol Ther 2012;36:91-103.

-30 Jiménez-Sousa MA, Fernández-Rodríguez A, Guzmán-Fulgencio $M$, García-Álvarez $M$, Resino S: Meta-analysis: implications of interleukin-28B polymorphisms in spontaneous and treatment-related clearance for patients with hepatitis C. BMC Med 2013;11:6.

-31 Lai M, Afdhal NH: Clinical utility of interleukin-28B testing in patients with genotype 1. Hepatology 2012;56:367-372.

- 32 Thomas DL, Thio CL, Martin MP, Qi Y, Ge D, O'Huigin C, Kidd J, Kidd K, Khakoo SI, Alexander G, Goedert JJ, Kirk GD, Donfield SM, Rosen HR, Tobler LH, Busch MP, McHutchison JG, Goldstein DB, Carrington M: Genetic variation in $I L 28 B$ and spontaneous clearance of hepatitis C virus. Nature 2009;461:798-801.
Tillmann HL, Thompson AJ, Patel K, Wiese $\mathrm{M}$, Tenckhoff $\mathrm{H}$, Nischalke HD, Lokhnygina Y, Kullig U, Göbel U, Capka E, Wiegand J, Schiefke I, Güthoff W, Grüngreiff K, König I, Spengler U, McCarthy J, Shianna KV, Goldstein DB, McHutchison JG, Timm J, Nattermann J; German Anti-D Study Group: A polymorphism near IL28B is associated with spontaneous clearance of acute hepatitis $\mathrm{C}$ virus and jaundice. Gastroenterology 2010;139: 1586-1592, 1592 e1.

34 Zheng MH, Li Y, Xiao DD, Shi KQ, Fan YC, Chen LL, Liu WY, Luo YW, Chen YP: Interleukin-28Brs12979860C/Tandrs8099917T/G contribute to spontaneous clearance of hepatitis C virus in Caucasians. Gene 2013;518: 479-482.

35 Rallón NI, Soriano V, Naggie S, Restrepo C, Goldstein D, Vispo E, McHutchison J, Benito JM: IL28B gene polymorphisms and viral kinetics in HIV/hepatitis C virus-coinfected patients treated with pegylated interferon and ribavirin. AIDS 2011;25:1025-1033.

-36 Sajadi MM, Shakeri N, Talwani R, Howell CD, Pakyz R, Redfield RR, Parsa A: IL28B genotype does not correlate with HIV control in African Americans. Clin Transl Sci 2011;4: 282-284.

- 37 Salgado M, Kirk GD, Cox A, Rutebemberwa A, Higgins Y, Astemborski J, Thomas DL, Thio CL, Sulkowski MS, Blankson JN: Protective interleukin-28B genotype affects hepatitis $C$ virus clearance, but does not contribute to HIV-1 control in a cohort of AfricanAmerican elite controllers/suppressors. AIDS 2011;25:385-387.

38 Martin MP, Qi Y, Goedert JJ, Hussain SK, Kirk GD, Hoots WK, Buchbinder S, Carrington M, Thio CL: IL28B polymorphism does not determine outcomes of hepatitis $\mathrm{B}$ virus or HIV infection. J Infect Dis 2010;202: 1749-1753.

- 39 O'Brien TR: Interferon-alfa, interferon-lambda and hepatitis C. Nat Genet 2009;41:10481050 .

40 Muir AJ, Shiffman ML, Zaman A, Yoffe B, de la Torre A, Flamm S, Gordon SC, Marotta P, Vierling JM, Lopez-Talavera JC, ByrnesBlake K, Fontana D, Freeman J, Gray T, Hausman D, Hunder NN, Lawitz E: Phase 1b study of pegylated interferon lambda 1 with or without ribavirin in patients with chronic genotype 1 hepatitis $C$ virus infection. Hepatology 2010;52:822-832.

-41 Thompson AJ, Muir AJ, Sulkowski MS, Ge D, Fellay J, Shianna KV, Urban T, Afdhal NH, Jacobson IM, Esteban R, Poordad F, Lawitz EJ, McCone J, Shiffman ML, Galler GW, Lee WM, Reindollar R, King JW, Kwo PY, Ghalib RH, Freilich B, Nyberg LM, Zeuzem S, Poynard T, Vock DM, Pieper KS, Patel K, Tillmann HL, Noviello S, Koury K, Pedicone LD, Brass CA, Albrecht JK, Goldstein DB, McHutchison JG: Interleukin-28B polymorphism improves viral kinetics and is the strongest pretreatment predictor of sustained virologic response in genotype 1 hepatitis $\mathrm{C}$ virus. Gastroenterology 2010;139:120-129 e18.

42 Hsu CS, Hsu SJ, Chen HC, Tseng TC, Liu CH, Niu WF, Jeng J, Liu CJ, Lai MY, Chen PJ, Kao $\mathrm{JH}$, Chen DS: Association of IL28B gene variations with mathematical modeling of viral kinetics in chronic hepatitis $\mathrm{C}$ patients with IFN plus ribavirin therapy. Proc Natl Acad Sci USA 2011;108:3719-3724.

43 Clark PJ, Thompson AJ: Host genomics and $\mathrm{HCV}$ treatment response. J Gastroenterol Hepatol 2012;27:212-222.

44 Chayama K, Hayes CN, Abe H, Miki D, Ochi H, Karino Y, Toyota J, Nakamura Y, Kamatani N, Sezaki H, Kobayashi M, Akuta N, Suzuki F, Kumada H: IL28B but not ITPA polymorphism is predictive of response to pegylated interferon, ribavirin, and telaprevir triple therapy in patients with genotype 1 hepatitis C. J Infect Dis 2011;204:84-93.

45 Thompson AJ, McHutchison JG: Will IL28B polymorphism remain relevant in the era of direct acting antiviral agents for HCV? Hepatology 2012;56:373-381.

-46 Smith BD, Morgan RL, Beckett GA, FalckYtter Y, Holtzman D, Teo CG, Jewett A, Baack B, Rein DB, Patel N, Alter M, Yartel A, Ward JW; Centers for Disease Control and Prevention: Recommendations for the identification of chronic hepatitis $\mathrm{C}$ virus infection among persons born during 1945-1965. MMWR Recomm Rep 2012;61:1-32.

47 Smith BD, Morgan RL, Beckett GA, FalckYtter Y, Holtzman D, Ward JW: Hepatitis C virus testing of persons born during 19451965: Recommendations from the centers for disease control and prevention. Ann Intern Med 2012;157:817-822.

48 US Department of Health and Human-Services: Combating the silent epidemic of viral hepatitis: action plan for the prevention, care and treatment of viral hepatitis. 2011. http:// www.liver.stanford.edu/resources/HHSactionplanintro.pdf.

49 Liu S, Cipriano LE, Holodniy M, Owens DK, Goldhaber-Fiebert JD: New protease inhibitors for the treatment of chronic hepatitis C: a cost-effectiveness analysis. Ann Intern Med 2012;156:279-290.

50 Gao X, Stephens JM, Carter JA, Haider S, Rustgi VK: Impact of adverse events on costs and quality of life in protease inhibitor-based combination therapy for hepatitis C. Expert Rev Pharmacoecon Outcome Res 2012;12: 335-343.

51 Lewden C, Salmon D, Morlat P, Bévilacqua S, Jougla E, Bonnet F, Héripret L, Costagliola D, May T, Chêne G; Mortality 2000 Study Group: Causes of death among human immunodeficiency virus (HIV)-infected adults in the era of potent antiretroviral therapy: emerging role of hepatitis and cancers, persistent role of AIDS. Int J Epidemiol 2005;34:121-130. 